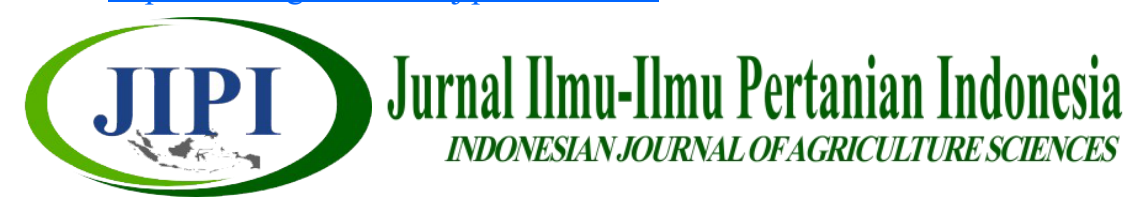

\title{
WAKTU PEMBERIAN LUMPUR SAWIT DAN DOSIS NPK PADA PERTUMBUHAN DAN HASIL JAGUNG MANIS (Zea mays saccharata Sturt.) DI ULTISOL
}

\author{
Daniel Malintang Siagian ${ }^{1}$, Bilman Wilman Simanihuruk ${ }^{1^{*}, \text { Herry Gusmara }^{2}}$ \\ ${ }^{1}$ Program Studi Agroekoteknologi, Fakultas Pertanian Universitas Bengkulu \\ ${ }^{1}$ Program Studi Ilmu Tanah, Fakultas Pertanian Universitas Bengkulu \\ * Corresponding Author : bilmanwilmansimanihuruk@yahoo.co.id
}

\begin{abstract}
[TIME OF GRANTING PALM OIL AND NPK DOSAGE IN GROWTH AND RESULTS OF SWEET CORN (Zea mays saccharata Sturt.) IN ULTISOL]. The objectives of this study were to obtain timing of sludge, NPK dosage and best interaction between NPK fertilizer and timing of sludge for growth and yield of sweet corn. The study was conducted from June to September 2017 at Jl. Al-Hikmah Mosque, Kandang Limun Village, Muara Bangkahulu Subdistrict, Bengkulu City with Ultisol soil type and altitude of $15 \mathrm{~m}$ above sea level. The study was arranged in Split Plot Design with two treatment factors and three replications. The first factor as the main plot was the time of giving of sludge 0,2 , and 4 weeks before planting, second factor as subplot was the application of each NPK dosage consisting of 3 treatment levels: $150 \mathrm{~kg} / \mathrm{ha}, 225 \mathrm{~kg} / \mathrm{ha}$, and $300 \mathrm{~kg} / \mathrm{ha}$. The timing of sludge and NPK doses gave no significant effect on the growth and yield of sweet corn. The timing of sludge two weeks before planting gives better results on the number of leaves. NPK was giving no significant effect on all observed variables.
\end{abstract}

Keyword: sweet corn, sludge, NPK, Ultisol

\begin{abstract}
ABSTRAK
Penelitian ini bertujuan untuk mendapatkan waktu pemberian lumpur sawit, dosis NPK dan interaksi antara pupuk NPK dan waktu pemberian lumpur sawit terhadap pertumbuhan dan hasil jagung manis di Ultisol. Penelitian dilakukan dari Juni hingga September 2017 di Jl. Masjid Al-Hikmah, Desa Kandang Limun, Kecamatan Muara Bangkahulu, Kota Bengkulu dengan jenis tanah Ultisol dan ketinggian $15 \mathrm{~m}$ di atas permukaan laut. Penelitian ini disusun dalam Split Plot Design dengan dua faktor dan tiga replikasi. Faktor pertama sebagai petak utama adalah waktu pemberian lumpur sawit yaitu 0, 2, dan 4 minggu sebelum tanam, faktor kedua sebagai subplot adalah dosis NPK yang terdiri atas tiga tingkat perlakuan yaitu $150 \mathrm{~kg} / \mathrm{ha}, 225 \mathrm{~kg} / \mathrm{ha}$, dan $300 \mathrm{~kg} / \mathrm{ha}$. Hasil penelitian menunjukkan interaksi yang tidak nyata antara waktu pemberian lumpur sawit dan dosis NPK pada semua variabel yang diamati. Waktu pemberian lumpur dua minggu sebelum tanam memberikan hasil yang lebih baik pada jumlah daun. Dosis NPK memberikan pengaruh yang tidak nyata terhadap pertumbuhan dan hasil jagung manis.
\end{abstract}

Kata kunci: jagung manis, lumpur sawit, pupuk NPK, Ultisol 


\section{PENDAHULUAN}

Jagung manis merupakan salah satu komoditas hortikultura yang cukup populer. Hal ini karena jagung manis memiliki potensi umur panen yang genjah (60-80 hari) dan memiliki rasa manis dibandingkan jagung biasa serta sesuai dikembangkan di daerah tropis (Samosir et al., 2014 ; Made, 2010).

Seiring dengan meningkatnya jumlah penduduk Indonesia, kebutuhan jagung manis nasional juga meningkat baik di tingkat konsumsi rumah tangga maupun produk olahan industri. Di lain sisi, peningkatan jumlah penduduk juga akan mendorong semakin sempitnya lahan pertanian. Faktor lainnya adalah kegunaan lahan di Indonesia yang kurang mendukung dalam pengembangan komoditas pertanian seperti pada lahan yang berordo Ultisol (Notohadiprawiro, 2006).

Mengingat keterbatasan Ultisol sebagai lahan yang kurang produktif bagi 6sektor pertanian Indonesia, maka perlu adanya terobosan teknologi budidaya pertanian yang tepat dan dapat menunjang produksi tanaman baik dari segi kualitas maupun kuantitas. Salah satu alternatif yang cukup tepat adalah intensifikasi lahan pertanian melalui pemupukan. Pemupukan NPK secara intensif mampu meningkatkan pertumbuhan dan produksi tanaman dengan dosis anjuran $300 \mathrm{~kg} / \mathrm{ha}$ (Mauke et al., 2015 ; Prasetya, 2014). Pemupukan sintetis saja belum cukup untuk meningkatkan produksi tanaman di Ultisol. Pemberian pupuk sintetis yang terus menerus hanya akan menambah residu kimia dalam tanah dan mengakibatkan kandungan senyawasenyawa organik menurun dalam tanah. Sehingga diperlukan pemupukan yang berimbang antara pupuk sintetis maupun organik guna meningkatkan produktivitas Ultisol. Hal ini sesuai dengan pendapat Sipayung et al. (2014) yang menyatakan bahwa terdapat interaksi positif antara pemberian pupuk sintetis dan pupuk organik terhadap produksi tanaman jagung.

Penggunaan pupuk organik di Indonesia masih tergolong rendah. Hal ini disebabkan pembuatan pupuk organik memerlukan waktu agar bahan organik terdekomposisi menjadi hara yang dibutuhkan tanaman. Konsekuensinya, unsur hara yang berasal dari pupuk organik belum optimal, dikarenakan bahan organik yang terus mengalami dekomposisi. Dekomposisi berlangsung untuk mengurai padatan bahan organik hingga menjadi pupuk organik. Kecepatan dekomposisi bahan organik ditunjukkan oleh perubahan imbangan $\mathrm{C} / \mathrm{N}$ selama mineralisasi secara bertahap yang cukup memakan waktu. Kriteria mutu bahan organik yang baik adalah nilai $\mathrm{C} / \mathrm{N}$ rasio berkisar $15 \%$, sedangkan waktu aplikasi pupuk organik yang baik dilakukan pada saat 2 minggu sebelum tanam (Litbang Pertanian, 2011; Sari et al., 2017).

Salah satu pupuk organik yang potensial dimanfaatkan adalah lumpur sawit yang dihasilkan dari pengolahan kelapa sawit. Limbah lumpur sawit yang dihasilkan mencapai 2\% dari produksi minyak (Subandriyo et al., 2010). Penumpukan limbah sawit secara terus menerus dapat berdampak negatif bagi lingkungan, sehingga perlu alternatif pemanfaatan limbah yang dapat menjadi potensi bagi aspek pertanian di Indonesia. Lumpur sawit mengandung unsur hara (per ton LS) sebesar $0,37 \% \mathrm{~N}$ (8 kg urea), 0,04\% P $(2,90 \mathrm{~kg} \mathrm{RP}), 0,91 \% \mathrm{~K}$ dan $0,08 \% \mathrm{Mg}(5 \mathrm{~kg}$ kiserit) (Darmawati et al., 2014). Oleh karena itu pemanfaataan limbah sawit sebagai pupuk organik mampu meningkatkan pertumbuhan dan hasil jagung (Wahyudi et al., 2011 ; Nugroho et al., 2016).

Mengingat hasil penelitian tentang pemanfaatan lumpur sawit dan pemberian pupuk majemuk NPK belum menunjukkan hasil yang konsisten maka perlu terus dilakukan penelitian tentang pemanfaatan lumpur sawit khususnya untuk tanaman jagung manis.. Tujuan dari penelitian ini adalah untuk mendapatkan waktu pemberian lumpur sawit, dosis NPK, dan interaksi antara waktu pemberian lumpur sawit dan dosis pupuk NPK terhadap pertumbuhan dan hasil jagung manis.

\section{METODE PENELITIAN}

Penelitian ini dilaksanakan dari bulan Juni September 2017 di Jl. Masjid Al-Hikmah, Kelurahan Kandang Limun, Kecamatan Muara Bangkahulu, Kota Bengkulu dengan jenis tahah Ultisol dan ketinggian tempat $15 \mathrm{~m}$ dpl. Penelitian disusun dalam Rancangan Petak Terbagi (Split Plot Design) yang terdiri atas dua faktor atas dasar acak kelompok. Faktor pertama sebagai petak utama adalah waktu pemberian lumpur sawit dengan dosis 15 ton/ha yang terdiri atas tiga taraf yaitu 0 minggu sebelum tanam (mst), 2 mst, dan 4 mst. Dosis pupuk NPK ditempatkan sebagai anak petak yang terdiri atas tiga taraf yaitu $150 \mathrm{~kg} /$ ha, $225 \mathrm{~kg} / \mathrm{ha}$, dan $300 \mathrm{~kg} / \mathrm{ha}$. Setiap perlakuan diulang tiga kali.

Data yang dikumpulkan meliputi variabel pertumbuhan dan hasil jagung manis yaitu tinggi tanaman (cm), jumlah daun (helai), total luas daun $\left(\mathrm{cm}^{2}\right)$, tingkat kehijauan daun, diameter batang $(\mathrm{cm})$, panjang tongkol berkelobot $(\mathrm{cm})$, diameter tongkol berkelobot $(\mathrm{cm})$, bobot tongkol berkelobot $(\mathrm{g})$, anjang tongkol tanpa kelobot $(\mathrm{cm})$, diameter tongkol tanpa kelobot $(\mathrm{cm})$, dan bobot tongkol tanpa kelobot $(\mathrm{g})$. Data yang diperoleh dianalisis secara statistik menggunakan Analisis Varians (ANAVA) pada taraf 5\%, dan dilanjutkan dengan uji Beda Nyata Terkecil (BNT) pada taraf 5\% (Yitnosumarto, 1991).

\section{HASIL DAN PEMBAHASAN}

Hasil analisis varians menunjukkan bahwa bahwa interaksi antara waktu pemberian lumpur sawit dan dosis NPK berpengaruh tidak nyata $(\mathrm{P}>0,05)$ terhadap keseluruhan variabel pengamatan. Waktu pemberian lumpur sawit nyata pengaruhnya $(\mathrm{P} \leq 0,05)$ hanya 
pada variabel jumlah daun. Pengaruh dosis pupuk NPK tidak nyata pada semua variabel amatan.

Kejenuhan Al yang tinggi dan $\mathrm{pH}$ rendah pada Ultisol diduga mengakibatkan tertekannya pertumbuhan dan perkembangan mikroorganisme dalam tanah. Keadaan demikian menunjukkan keadaan lingkungan yang tidak baik bagi mikroorganisme dalam tanah sehingga mengakibatkan hal yang serupa bagi pertumbuhan dan hasil tanaman. Mukhtaruddin et al. (2014) menjelaskan lebih lanjut bahwa pemberian bahan organik dan pupuk an organik tidak memberikan dampak positif terhadap kandungan unsur hara dalam tanah masam. Pemberian bahan organik seharusnya mampu meningkatkan $\mathrm{pH}$ tanah jika pengapuran juga dilakukan karena sifat kimia basa yang terkandung di dalamnya dapat menununkan kejenuhan sifat masam Ultisol. Pengapuran pada tanah kering masam menyebabkan kandungan N, P, K berharkat "tinggi", sedangkan $\mathrm{Ca}, \mathrm{Mg}$, dan Fe berharkat "cukup" pada tanaman ubi kayu (Ispandi \& Munip, 2005).

Lokasi penelitian tidak pernah dilakukan pengapuran. Analisis $\mathrm{pH}$ tanah yang dilakukan menunjukkan nilai 4,8 yang berarti kriteria $\mathrm{pH}$ tanah lahan penelitian masuk dalam golongan hampir sangat masam. Ketersediaan unsur hara, kualitas pertumbuhan, dan hasil tanaman pada kondisi tersebut menjadi tidak sesuai dengan yang diharapkan (Sastramihardja et al., 2009).

Waktu pemberian lumpur sawit hanya memberikan pengaruh yang nyata terhadap jumlah daun tanaman jagung manis dengan nilai rata-rata terbanyak 10,67 helai. Waktu pemberian lumpur sawit 0 minggu sebelum tanam (saat tanam) sampai 2 minggu sebelum tanam secara nyata meningkatkan jumlah daun dari 10,24 helai menjadi 10,67 helai (Tabel 1). Jumlah daun terbanyak ini dijumpai pada perlakuan waktu pemberian lumpur sawit 2 minggu sebelum tanam. Berdasarkan data ini diduga bahwa waktu pemberian lumpur sawit saat tanam telah mengalami mineralisasi yang baik sebelum diaplikasikan, sehingga ketersediaan hara dalam tanah tercukupi pada aplikasi saat tanam dan menurun ketersediaannya semakin lama tertimbun dalam tanah karena bahan organik yang terus melakukan dekomposisi (Atmojo, 2003). Asngad (2013) menjelaskan bahwa pupuk organik melakukan dekomposisi seiring dengan tingkat kematangan bahan organik dan memiliki fungsi kimia dalam penyediaan hara makro seperti N, P, K dan hara mikro yang relatif lengkap seperti $\mathrm{Na}, \mathrm{Zn}, \mathrm{Cu}, \mathrm{Co}, \mathrm{Ba}, \mathrm{Mn}$, dan Fe. Peningkatan waktu pemberian pupuk organik pada tanaman diiringi dengan laju peningkatan jumlah daun tanaman. Hal ini terjadi karena kandungan hara dalam pupuk organik sebagai bahan penting penyusun jaringan tanaman terus melakukan pelepasan hara dari hasil dekomposisi (Setiaaji et al., 2017).

Pengaruh perlakuan yang tidak nyata diduga disebabkan oleh karakter Ultisol yang memiliki sifat fisik, biologi dan kimia tanah yang buruk sehingga pemberian bahan organik dan pemupukan belum mampu mendukung pertumbuhan tanaman. Pemberian bahan organik pada tanah masam dalam kurun waktu yang cukup lama dapat mengakibatkan akumulasi $\mathrm{K}$ serta defisiensi $\mathrm{N}$ dan $\mathrm{Mg}$ sehingga menurunkan kegunaannya bagi pertumbuhan dan hasil tanaman (Refliaty \& Marpaung, 2010; Suriadikarta \& Setyorini, 2006). Berdasarkan hasil analisis tanah lahan penelitian menyatakan kandungan kadar air, $\mathrm{N}, \mathrm{P}$, dan $\mathrm{K}$ serta $\mathrm{pH}$ tanah secara urut yaitu $8,21 \%, 0,317 \%, 1,75 \mathrm{ppm}, 0,46 \mathrm{me} / 100 \mathrm{~g}$, dan 4,8 dengan kriteria rendah (Sinambela, 2017 ; Sastramihardja, 2009).

Penimbunan bahan organik dalam jangka waktu yang cukup lama dalam tanah masam menyebabkan tertekannya pertumbuhan dan perkembangan mikroorganisme yang berperan melakukan dekomposisi unsur hara. Hal tersebut berdampak pada efektifitas hara dalam bahan organik belum tersedia cukup bagi tanaman untuk menyelesaikan siklus hidupnya (Atmojo, 2003).

Dosis NPK secara tunggal berpengaruh tidak nyata terhadap semua variabel pengamatan. Nilai rata-rata dan penjelasan secara deskriptif menggunakan teori pendugaan. Rangkuman nilai rata-rata disajikan pada Tabel 1.

Pemberian pupuk NPK dan lumpur sawit belum mampu memperbaiki permasalahan yang ada pada Ultisol. Syahputra et al. (2015) menyatakan Ultisol memiliki kejenuhan $\mathrm{Al}$ yang tinggi, $\mathrm{pH}$ rendah, dan kadar organik dalam tanah yang rendah sehingga unsur hara tersedia dalam tanah banyak terikat dan berdampak negatif pada tanaman dalam memperoleh unsur hara. Pemberian pupuk NPK tidak menimbulkan dampak positif terhadap keseluruhan variabel generatif tanaman jagung manis (Masni et al., 2015 ; Suntoro \& Astuti, 2014). Pengapuran di Ultisol berdampak positif terhadap serapan hara oleh tanaman dan meningkatkan produktivitas Ultisol sebagai lahan budidaya tanaman (Ispandi \& Munip, 2005).

Pemberian dosis NPK $150 \mathrm{~kg}$ ha sampai dosis NPK 300 $\mathrm{kg} /$ ha menghasilkan pertumbuhan dan hasil tanaman jagung manis yang berbeda tidak nyata. Pemberian dosis pupuk NPK $150 \mathrm{~kg}$ ha secara konsisten menghasilkan nilai tertinggi secara keseluruhan pada variabel yang diamati. Dosis NPK tersebut telah efektif mendukung pertumbuhan dan hasil tanaman sehingga peningkatan dosis akan mengakibatkan penurunan pertumbuhan dan hasil tanaman. Hal ini sesuai dengan pendapat Djamaan (2006) bahwa peningkatan pemberian N pada tanaman selada cenderung menunjukkan penurunan tinggi tanaman, panjang daun, lebar daun, diameter tajuk dan produksinya. Dominasi faktor lingkungan seperti suhu, kelembaban, sifat tanah dan curah hujan lebih intensif menyebabkan laju pertumbuhan tanaman menjadi tertekan dan tidak sesuai dengan apa yang diharapkan. 
Tabel 1. Pengaruh pemberian lumpur sawit dan NPK terhadap pertumbuhan dan hasil tanaman jagung

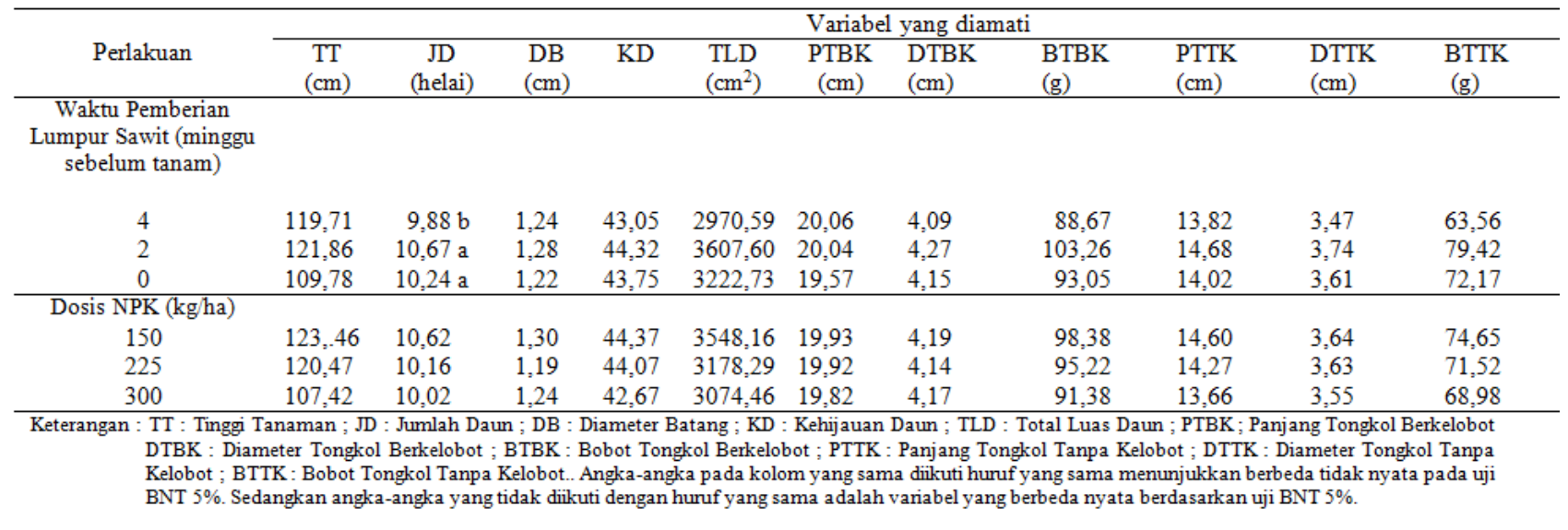

Sesuai dengan pendapat Makarim (2006) bahwa keracunan Al dan Fe pada tanah masam, cekaman kekeringan mengakibatkan penurunan kualitas pertumbuhan dan produksi tanaman. Hal ini diperkuat dengan hasil penelitian padi oleh Noor \& Khairuddin (2013) yang menunjukkan bahwa kandungan Fe dalam tanah rawa dan gambut yang tinggi mengakibatkan penurunan kadar hara $\mathrm{Ca}, \mathrm{Mg}$, dan $\mathrm{P}$ dalam tanah. Dampaknya tanaman mengandung besi dan pertumbuhan tanaman menjadi tertekan. Sementara disisi lain, hasil analisis $\mathrm{pH}$ tanah lahan penelitian berordo ultilos yang juga menunujukkan keadaan yang masam yakni 4,8, menyebabkan kualitas pertumbuhan dan hasil tanaman tidak sesuai dengan apa yang diharapkan (Sastramihardja et al., 2009).

\section{KESIMPULAN}

Berdasarkan hasil penelitian ini dapat disimpulkan bahwa waktu pemberian lumpur sawit dan dosis NPK memberikan pengaruh tidak nyata terhadap pertumbuhan dan hasil jagung manis. Waktu pemberian lumpur sawit saat tanam dan 2 minggu sebelum tanam memberikan hasil yang lebih baik pada variabel jumlah daun. Pemberian NPK berpengaruh tidak nyata terhadap variabel pertumbuhan dan hasil jagung manis.

\section{DAFTAR PUSTAKA}

Asngad, A. (2013). Inovasi pupuk organik kotoran ayam dan enceng gondok dikombinasi dengan bioteknologi mikoriza bentuk granul, J. MIPA, 36(1), 1-7.

Atmojo, S. W. (2003). Peranan bahan organik terhadap kesuburan tanah dan upaya pengelolaannya. Orasi Ilmiah, Guru Besar Ilmu Kesuburan Tanah, Fakultas Pertanian, Universitas Sebelas Maret, Surakarta.

Darmawati, J. S., Nursamsi \& Siregar, A.R. (2014). Pengaruh pemberian limbah padat (sludge) kelapa sawit dan pupuk organik cair terhadap pertumbuhan dan produksi tanaman jagung manis (Zea mays saccharata.), J. Agrium, 19 (1), 59-67.

Djamaan, D. (2006). Pemberian Nitrogen (Urea) terhadap Pertumbuhan dan Hasil Selada (Lactuca sativa L.), BPTP Sumatra Barat, Provinsi Sumatra Barat.

Ispandi, A. \& Munip, A. (2005). Efektifitas pengapuran terhadap serapan hara dan produksi beberapa kon ubi kayu di lahan kering masam, J. Ilmu Pertanian, 12(2), 125-139.

Litbang Pertanian. (2011). Ragam inovasi pendukung pertanian daerah, Agroinovasi, E. 3-9 Agustus 2011 No. 3417

Made, U. (2010). Respon berbagai populasi tanaman jagung manis (Zea mays saccharata Sturt.), J. Agroland, 17(2), 138-143.

Makarim, A. K. (2006). Cekaman Abiotik Utama dalam Peningkatan Produktivitas Tanaman. Balai Penelitian Tanaman Padi, Sukamandi

Masni, E. R., Bintang \& Marpaung, P. (2015). Pengaruh interaksi bahan mineral dan bahan organik terhadap sifat kimia Ultisol dan produksi tanaman sawi, J. Online Agroekoteknologi, 3 (4), 1489-1494.

Mauke, S., M. I. Bahua, \& Nurmi. (2015). Pertumbuhan dan produksi jagung manis (Zea mays saccharata L.), J. Agroteknotropika, 4 (1), 1-7.

Mukhtaruddin, Sufardi, A. \& Anhar. (2014). Pengunaan guano dan pupuk NPK-mutiara untuk memperbaiki kualitas media subsoil dan pertumbuhan bibit kelapa sawit (Elais guineensis Jacq), J. Floratek, 9, 69-82.

Noor, A. \& Khairuddin. (2013). Keracunan Besi pada Padi : Aspek Ekologi dan Fisiologi-Agronomi, S. Inovasi Teknologi Pertanian, BPTP, Kalimantan Selatan

Notohadiprawiro, T. (2006). Pertanian Lahan Kering di Indonesia : Potensi, Prospek, kendala, dan 
Pengembangannya, Repro Ilmu Tanah Universitas Gadjah Mada, Riset Nasional bidang Sumber Daya Alam, Energi, dan Lingkungan

Nugroho, J. S., Gusmara, H. \& Simanihuruk, B.W. (2016). Pengaruh lumpur sawit dan NPK sintetik terhadap pertumbuhan dan hasil tanaman jagung, $J$. Agritrop Ilmu-ilmu Pertanian, 14(2), 114-119.

Prasetya, M. E. (2014). Pengaruh pupuk NPK mutiara dan pupuk kandang sapi terhadap pertumbuhan dan hasil tanaman cabai merah keriting varietas arimbi (Capsicum annum L.), J. Agrifor, 13(2), 191-198.

Refliaty \& Marpaung, E.J. (2010), Kemantapan agregat Ultisol pada beberapa penggunaan lahan dan kemiringan lereng, J. Hidrolitan, 1(2), 35-42.

Samosir, A. T. H., J. M. P. Sumampow, \& S. Tumbelaka. (2014). Pemberian kompos jerami padi terhadap pertumbuhan dan produksi tanaman jagung manis (Zea mays saccharata Sturt.), Budidaya Pertanian Fakultas Pertanian Sam Ratulangi, Tomohon

Sari, D. P., Simanihuruk, B.W. \& Gusmara, H. (2017). Pertumbuhan dan hasil jagung manis (Zea mays Saccharata Sturt L.) dengan pengurangan pupuk NPK yang digantikan dengan lumpur kelapa sawit (Sludge) pada tanah Ultisol, J. Agritrop, 15(1), 138-151.

Sastramihardja, H., S. E. Apriliani \& Manalu, F. (2009). Analisis Kimia Tanah, Tanaman, Air dan Pupuk. Balittanah, Bogor

Setiaaji, A. S., Mandang, J. Sh. P. \& Paulus, J.M. (2017). Produksi jagung (Zea mays saccharata L.) berbagai kompos jerami dan pupuk organik cair daun gamal, J. Eugenia, 23(1), 16-26.
Sinambela, A. M. L. (2017). Hasil analisis kadar air, N-total, P-bray, dan K-dd. Laboratorium Tanah, Tanaman, Pupuk, Air, Balai Pengakajian Teknologi Pertanian, Bengkulu.

Sipayung, E. S., G. Sitanggang, \& M. M. B. Damanik. (2014), Perbaikan sifat fisik dan kimia Ultisol Simalingkar B Kecamatan Pancur Batu dengan pemberian pupuk organik Supernasa dan Rockphosphit serta pengarunya terhadap produksi tanaman jagung (Zea mays L.). J. Online Agroekoteknologi, 2(2), 393-403.

Subandriyo, Kurnia, A., Hastuti, E.T. \& Susdawanita. (2010). Fermentasi limbah padat industri kelapa sawit (Solid Heavy Phase). J. Teknologi Pencegahan dan Pencemaran Industri, 1(2), 124-130.

Suntoro \& Astuti, P. (2014). Pengaruh waktu pemberian dan dosis pupuk NPK pelangi terhadap pertumbuhan tanaman jagung manis varietas sweet boys (Zea mays saccharata Sturt.). J. Agrifor, 13(2), 213-222.

Suriadikarta, D. A. \& Setyorini, D. (2006). Baku Mutu Pupuk Organik. Balitbang Sumberdaya Lahan Pertanian, Bogor, Jawa Barat.

Syahputra, E., Fauzi \& Razali. (2015). Karakteristik sifat kimia sub grup tanah ultisol di beberapa Wilayah Sumatra Utara. J. Agroekoteknologi, 4 (1), 1796-1803.

Wahyudi, H., Kasry, A. \& Purwaningsih, I.S. (2011). Pemanfaatan limbah cair kelapa sawit untuk memenuhi kebutuhan unsur hara dalam budidaya tanaman jagung (Zea mays L.), J. Ilmu Lingkungan, 5(2), 94-102.

Yitnosumarto, S. (1991). Percobaan : Perancangan, Analisis, dan Interpretasinya. Gramedia, Jakarta. 